\title{
PHARMACOLOGICAL POTENTIAL OF ENDOTHELIN RECEPTORS AGONISTS AND ANTAGONISTS
}

\author{
Jiři Patočka ${ }^{1,2}$, Vladimír Měrka1, Vratislav Hrdina, Radomír Hrdina ${ }^{3}$ \\ University of Defence in Brno, Faculty of Military Health Sciences in Hradec Králové, Czech Republic: Department of \\ Toxicology1; University of South Bohemia, České Budějovice, Faculty of Health and Social Studies, Czech Republic: \\ Department of Radiology and Toxicology2; Charles University in Prague, Faculty of Pharmacy in Hradec Králové, Czech \\ Republic: Department of Pharmacology and Toxicology ${ }^{3}$
}

\begin{abstract}
Summary: Endothelins are potent predominantly vasoconstricting agents that act as local autocrine and paracrine mediators. Endothelin-1 is the most potent and sustained vasoconstrictor and pressor substance yet identified. Abnormalities of the endothelin system occur in a range of diseases associated with vasoconstriction, vasospasm, and vascular hypertrophy. ET receptor antagonists were until recently regarded as drugs of great promise in patients with congestive heart failure, pulmonary hypertension and others. The aim of this article is a survey of compounds that affect the endothelin receptors and clinical trials with these agents.
\end{abstract}

Key words: Endothelin; Endothelin receptor; Endothelin receptor agonist; Endothelin receptor antagonist; Bosentan; Pulmonary hypertension treatment

\section{Introduction}

The endothelin (ET) family of peptides are very potent endogenous vasoconstrictors and pressor agents, secreted by various cells and tissues in the human. The ET family consists of 3 structurally similar isopeptides: ET-1,-2, and -3. The genes that encode these peptides are cloned and are found to be on chromosomes 6,1 and 20, respectively (14). Of the three isoforms, endothelin ET-1 is the predominant isoform produced by the vascular endothelium. ET-1 is synthesized in the human vasculature and is the most potent vasoconstrictor substance known (32). ET-2 has similar vasoconstrictor potency to ET-1 and appears to be synthesized predominantly in the kidney and intestines (13). ET-3 is the least potent vasoconstrictor. It is detectable in the central nervous system, lungs, kidneys, pancreas and spleen (12). All the three endogenous isoforms of ET in humans mediate their actions via two ET receptor subtypes: $\mathrm{ET}_{\mathrm{A}}$ and $\mathrm{ET}_{\mathrm{B}}$. These ETs play an important role in human physiology and in the pathophysiology of vasospastic conditions, renal failure, chronic heart failure and asthma (10). Chemical compounds that interact with ET receptors, natural and/or synthetic agonists and antagonists, respectively, represent important group of substances with weighty pharmacological potential (23). Because ETs were thought to be important in cardiovascular homeostasis, many investigators focused on the physiological and pathophysiological significance of ET. Accordingly, ET receptor antagonists have been developed rapidly, mostly for the treatment of cardiovascular diseases (11). The current review will focus on the recent developments in the endothelin field, with special emphasis on the ET-1 antagonists and their clinical use.

\section{Endothelins}

ETs represent a family of 21-amino acid peptides whose structure consists of two rings formed by intra-chain disulfide bonds and a linear C-terminal tail. These peptides were originally described on the basis of their potent vasoconstrictor activity (27). The three peptides are encoded by three different genes. Biologically active endothelins are produced from pre-pro-polypeptides through two steps of proteolytic processing. The approximately 200 -residue prepro-endothelins are first processed by a furin-like processing protease(s) into biologically inactive intermediates termed big endothelins (big ETs) (25). These are further proteolytically cleaved between $\operatorname{Trp}^{21}$ and $\mathrm{Val} / \mathrm{Ile}^{22}$ to produce active endothelins. This proteolytic conversion is catalyzed by specific endothelin-converting enzymes (ECEs). Two isozymes of ECE, ECE-1 and ECE-2, have been molecularly identified. Both these enzymes are membrane proteins with highly conserved $\mathrm{Zn}^{2+}$ metalloprotease motifs.

The ECE- 1 cleaves big endothelins at a neutral $\mathrm{pH}$, while ECE-2 functions in an acidic $\mathrm{pH}$ range. This implies that these enzymes function in different subcellular locations: ECE-1 may act in early components of the secretory path- 
way, presumably in the Golgi apparatus, as well as on the cell surface. In contrast, ECE-2 probably functions in highly acidified compartments of the secretory pathway, including a portion of the trans-Golgi apparatus. These isozymes also appear to have different functions during embryonic development (9). Targeted disruption of the ECE-1 gene in mice revealed that ECE-1 is the major enzyme involved in the activation of big ET-1 and big ET-3 at specific developmental stages. Importantly, it appears that loss of ECE-1 protein cannot be compensated for by ECE-2.

\section{Endothelin receptors}

$\mathrm{ET}_{\mathrm{A}}$ and $\mathrm{ET}_{\mathrm{B}}$ have been isolated and cloned from human tissues (2). Both subtypes belong to the seven-transmembrane-domain-spanning, G-protein-coupled receptor superfamily (6). ET receptors are widely expressed in all tissues, consistent with the physiological role of ET-1, the most abundant isoform, as a ubiquitous endothelium-derived vasoactive peptide contributing to the maintenance of

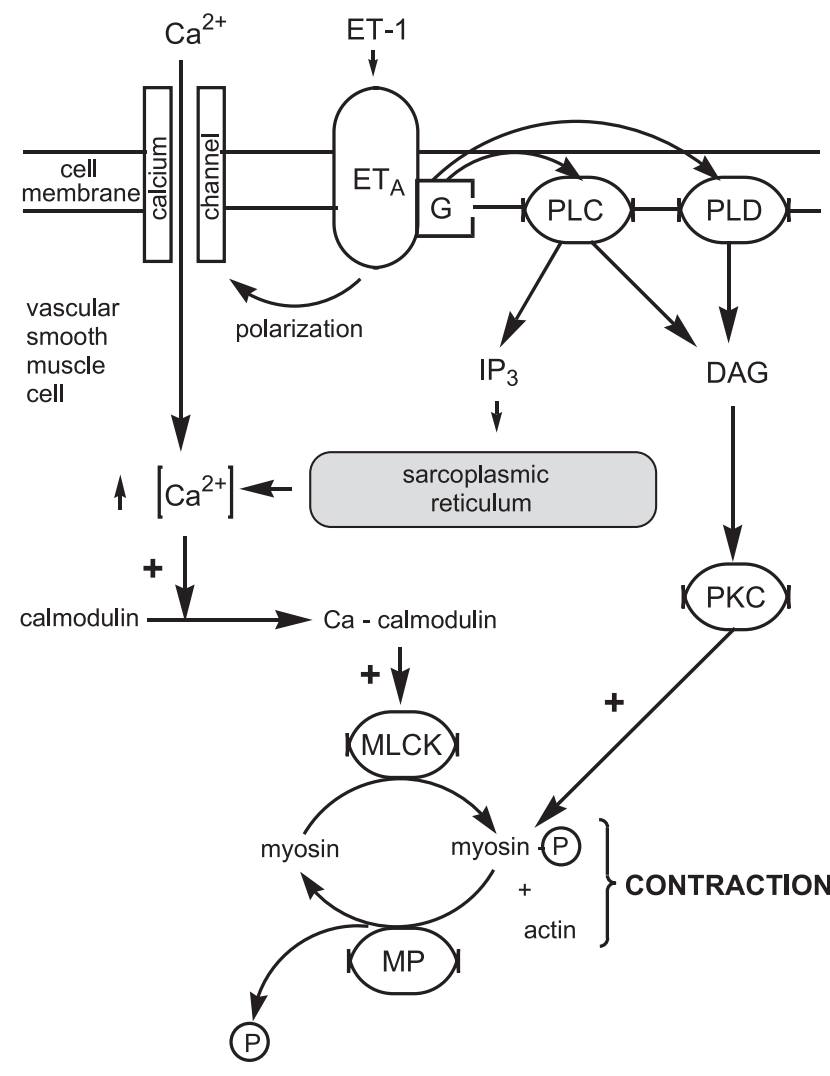

Fig. 1: Mechanism of contraction of vascular smooth muscle caused by endothelin-1 (According to Potaczek and Sanak, 2002). Abbreviations used: ETA - endothelin receptor of type A, G - G-protein coupled receptor, PLC - phospholipase C, PLD - phospholipase D, IP $\mathbf{P}_{\mathbf{3}}$ - inositol trisphosphate, DAG - diacylglycerol, PKC - protein kinase C, MLCK - myosinlight-chain dinase, MP - myosin phosphatase. normal vascular tone. ET receptors are also localized to non-vascular structures, such as epithelial cells, and expressed in the central nervous system. ET-1 stimulates proliferation in a number of different cell types, including smooth muscle cells (mainly via the $\mathrm{ET}_{\mathrm{A}}$ subtype) and astrocytes (via $\mathrm{ET}_{\mathrm{B}}$ ). In human blood vessels, $\mathrm{ET}_{\mathrm{A}}$ receptors are present mainly on vascular smooth muscle cells, and are chiefly responsible for contraction whereas $\mathrm{ET}_{\mathrm{B}}$ receptors mediate vasodilatation. The mechanisms of $\mathrm{ET}_{\mathrm{A}}$ activation by endothelins and signal transfer mechanism of vascular smooth muscle contraction is schematically shown in Fig 1 [according to Potaczek and Sanak (26)]. ET B $_{\mathrm{B}}$ receptors are also localized in the single layer of endothelial cells lining the vessel wall. Activation of endothelial $\mathrm{ET}_{\mathrm{B}}$ receptors may lead to the release of endothelium-derived relaxing factors (nitric oxide and prostanoids).

ET-1 has dual vasoactive effects, mediating vasoconstriction via $\mathrm{ET}_{\mathrm{A}}$ receptor activation of vascular smooth muscle cells and vasorelaxation via $\mathrm{ET}_{\mathrm{B} 1}$ receptor activation of endothelial cells. $\mathrm{ET}_{\mathrm{B}}$-receptor is also present in vascular smooth musle like $\mathrm{ET}_{\mathrm{A}}$-receptor. The receptor on endothelium has been called $\mathrm{ET}_{\mathrm{B} 1}$, while the vascular

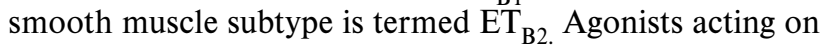
$\mathrm{ET}_{\mathrm{B} 1}$ cause, as already mentioned, vasodilation. In contrast, $\mathrm{ET}_{\mathrm{B} 2}$-mediated responses are vasoconstrictor, like responses mediated by $\mathrm{ET}_{\mathrm{A}}$. Vasodilation is, at least partly, caused by stimulation of nitric oxide (NO) synthesis and $\mathrm{PGI}_{2}$ synthesis, however, the precise signal tranduction is unknown (21).

Non-vascular $\mathrm{ET}_{\mathrm{B}}$ receptors in organs including the kidney may beneficially clear ET-1 from the circulation (6). All these receptors have become important targets for drugs developed to inhibit vasoconstrictor actions (19).

It is widely accepted that the vascular, cardiac, and renal adverse effects of ET-1 are mediated by $\mathrm{ET}_{\mathrm{A}}$, while activation of $\mathrm{ET}_{\mathrm{B}}$ receptors leads to beneficial effects such as: attenuating the vascular and cardiac hypertrophic effects of ET-1 as well as the vasodilatory action of this peptide (1).

\section{Endothelin receptors agonists}

Natural ET agonists are all endogenous ET isoforms and ET receptors to be classified according to their rank order of potency for the individual ETs (5). Other natural ET agonists are sarafotoxins, toxic peptides from the venom of mole viper Atractaspis engaddensis (burrowing asp), which may pose a serious threat to humans. At present, four sarafotoxins (STX) are known: S6a, S6b, S6c, and S6d $(3,30)$. A new member of the endothelin/sarafotoxin family of vasoconstrictor peptides, bibrotoxin (BTX), was isolated from the venom of the burrowing asp Atractaspis bibroni (4). The primary structure of all known endothelins, sarafotoxins and bibrotoxin are summarized in Tab. 1. They are 21-amino acid peptides with high degree of similarity whose structure consists of two rings formed by intra-chain disulphide bonds. 
Tab. 1: The sequence of amino acid residues in endothelin family peptides.

Nowadays three endothelins (ET), four sarafotoxins (SFTX) and bibrotoxins are known. All these peptides have 21 amino acids and two disulphide bridges between $\mathrm{Cys}^{1}-\mathrm{Cys}^{15}$ and between $\mathrm{Cys}^{3}-\mathrm{Cys}^{11}$.

\begin{tabular}{|c|c|}
\hline & 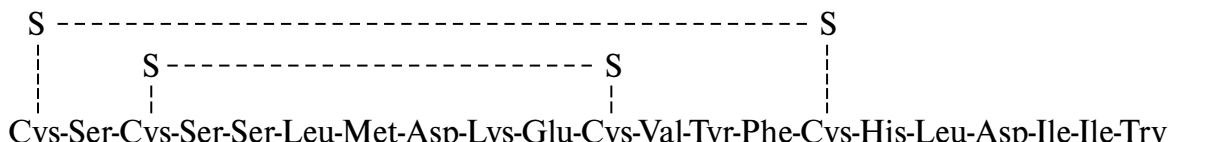 \\
\hline $\begin{array}{l}\text { EI-1 } \\
\text { ET-2 }\end{array}$ & Cys-Ser-Cys-Ser-Ser-Tyr-Leu-A sn-L vs-Glu-Cys-Val-Tyr-Phe-Cys-His-Leu-Asn-Ile-Ile-Try \\
\hline ET-3 & Cys-Thr-Cys-Phe-Thr-Tyr-Lys-Asp-Lys-Glu-Cys-Val-Tyr-Tyr-Cys-His-Leu-Asp-Ile-Ile-Try \\
\hline SFTX S6a & Cys-Ser-Cys-Lys-Asp-Met-Thr-Asp-Lys-Glu-Cys-Leu-Asn-Phe-Cys-His-Gln-Asp-Val-Ile-Try \\
\hline SFTX S6b & Cys-Ser-Cys-Lys-Asp-Met-Thr-Asp-Lys-Glu-Cys-Leu-Tyr-Phe-Cys-His-Gln-Asp-Val-Ile-Try \\
\hline SFTX S6c & Cys-Ser-Cys-Asn-Asp-Met-Thr-Asp-Glu-Glu-Cys-Leu-Asn-Phe-Cys-His-Gln-Asp-Val-Ile-Try \\
\hline SFTX S6d & Cys-Thr-Cys-Lys-Asp-Met-Thr-Asp-Lys-Glu-Cys-Leu-Tyr-Phe-Cys-His-Gln-Asp-Ile-Ile-Try \\
\hline Bibrotoxin & Cys-Ser-Cys-Ala-Asp-Met-Thr-Asp-Lys-Glu-Cys-Leu-Tyr-Phe-Cys-His-Gln-Asp-Val-Ile-Try \\
\hline
\end{tabular}

Tab. 2: Classification of ET receptors agonists and antagonists.

\begin{tabular}{|c|c|}
\hline Selectivity/Company & Company code and chemical structure \\
\hline \\
\hline \multirow[t]{2}{*}{ Peptide agonists: } & {$\left[\mathrm{D}-\mathrm{Lys}^{9}\right] \operatorname{cyclo}(11-15) \mathrm{ET}-1(9-21)$} \\
\hline & {$\left[\mathrm{Ala}^{11,15}, \operatorname{Trp}(\text { For })^{21}\right] \mathrm{ET}-1(9-21)$} \\
\hline \multirow[t]{6}{*}{ Peptide antagonists: } & BQ123 = BE18257A = cyclo-[D-Asp-L-Pro-D-Val-L-Leu-D-Trp-] \\
\hline & BQ153 \\
\hline & BQ485 = hexahydro-1H-azepinyl)carbonyl- D-Leu-D-Trp-OH \\
\hline & BQ610 = homopiperidenyl-CO-Leu-D-Trp-CHO-D-Trp-OH \\
\hline & FR139317 = N-[(hexahydro-1-azepinyl)carbonyl]L-Leu(1-Me)D-Trp ${ }^{3}$ (2-pyridyl)-D-Ala \\
\hline & PD151242 = Tyr ${ }^{3}-(\mathrm{N}-[($ hexahydro-1H-azepin-1-yl)carbonyl]-L-Leu]-1Me)-D-Trp \\
\hline Non-peptide antagonists: & A127722 \\
\hline \multirow[t]{4}{*}{ Abbott (Knoll) } & A216546 \\
\hline & ABT627 $($ A147627 $)=$ active enantiomer of the racemate A127722 \\
\hline & $\begin{array}{l}\text { LU127043 = 2-(4,6-dimethoxy-pyrimidin-2-yloxy)-3-methoxy-3,3-diphenyl-propionic } \\
\text { acid }\end{array}$ \\
\hline & $\begin{array}{l}\text { LU135252 }=(+)-S-2-(4,6 \text {-dimethoxy-pyrimidin-2-yloxy)-3-methoxy-3,3-diphenyl- } \\
\text { propionic acid }\end{array}$ \\
\hline \multirow[t]{3}{*}{ Bristol-Myers Squibb } & $\begin{array}{l}\text { BMS182874 = 5-(dimethylamino)-N-(3,4-dimethyl-5-isoxazolyd)-1-naphthalene } \\
\text { sulfonamide }\end{array}$ \\
\hline & BMS184696 \\
\hline & BMS184697 \\
\hline ImmunoPharmaceuticals Inc & IPI413 \\
\hline \multirow[t]{5}{*}{ Pfizer (Parke-Davis) } & $\begin{array}{l}\text { PD156707 (=CI1020; 8-8.7) = sodium 2-benzo(1,3)dioxol-5-yl-4-(4-methoxy-phenyl)-4- } \\
\text { oxo-3-(3,4,5-trimethoxybenzyl)-but-2-enoate }\end{array}$ \\
\hline & $\begin{array}{l}\text { PD155080 (8-8.5), PD155719 = sodium 2-benzo\{1,3\}dioxol-5-yl-3-benzyl-4-(4-methoxy- } \\
\text { phenyl-)-4-oxobut-2-enoate }\end{array}$ \\
\hline & PD159433 \\
\hline & PD163070 \\
\hline & PD164893 \\
\hline Peptide International & PED3512PI \\
\hline Hoffman-LaRoche & RO611790 \\
\hline
\end{tabular}




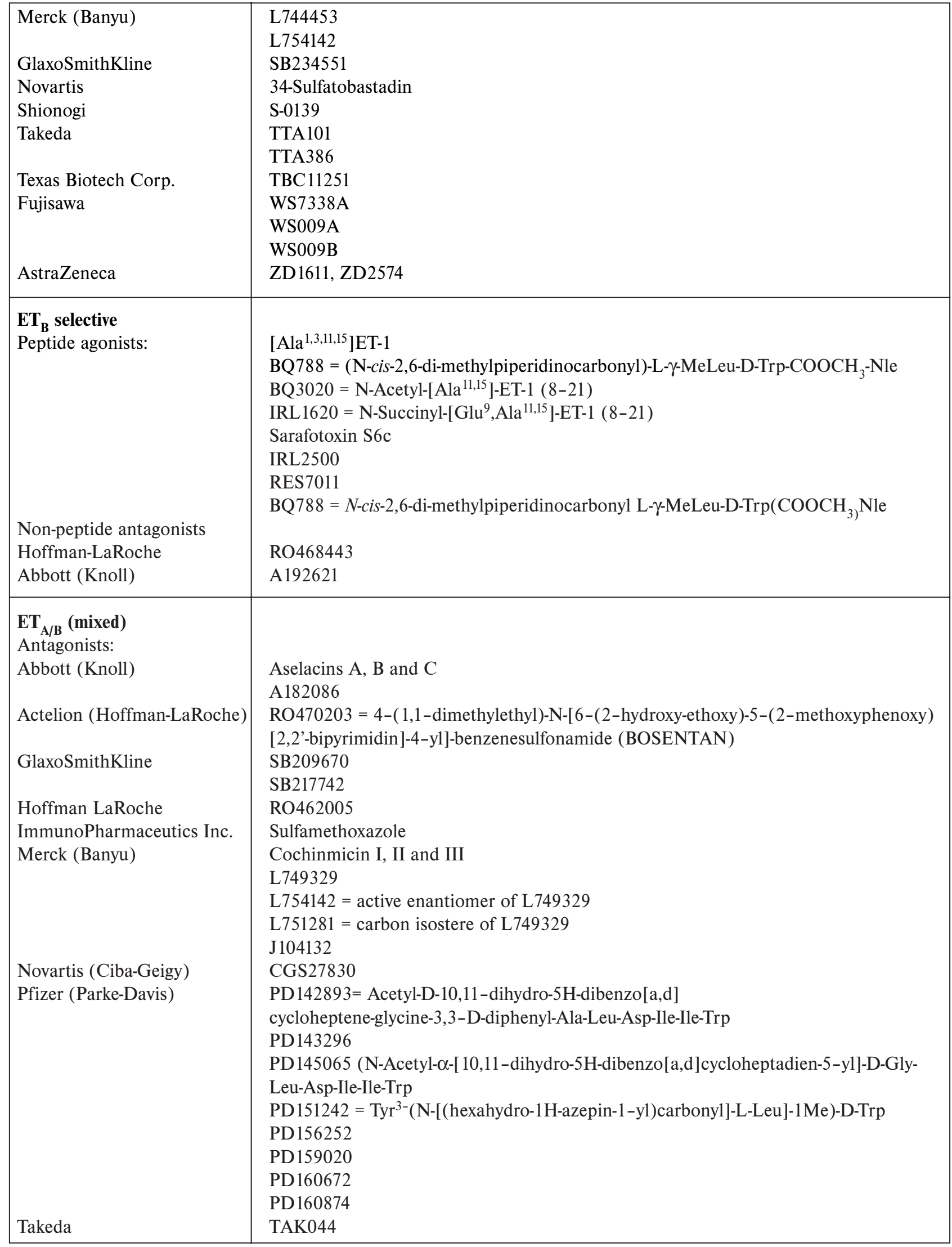


The venom from the snake $A$. engaddensis has a very high lethal potency, with an i.v. $\mathrm{LD}_{50}$ of $0.06-0.075 \mathrm{mg} . \mathrm{kg}^{-1}$ body weight in mice. The onset of action of the venom is rapid (30-45 $\mathrm{min}$ ) and death results from seemingly neurotoxic effects. However, even at high concentrations, the venom does not block contractions of skeletal muscles that are directly or indirectly stimulated. The changes observed in the ECG are similar to those recorded in human victims (18) and are the result of an A-V block that is caused by an apparent direct action of the venom on the heart (34). Concerning ETs already a low dose of ET-1 has a lethal effect in experimental animals by inducing disturbances in the cardiovascular system (16).

Endothelins and sarafotoxins are not selective agonists of $\mathrm{ET}_{\mathrm{A}}$ and $\mathrm{ET}_{\mathrm{B}}$ receptors. Until now, non-selective $\mathrm{ET}_{\mathrm{A}}$ receptor agonists have been described in the literature. Recently, [D-Lys ${ }^{9}$ ]cyclo(11-15) ET-1(9-21) was described as a specific full agonist of $\mathrm{ET}_{\mathrm{A}}$ receptors, being under two orders less potent than ET-1 ( $\mathrm{EC}_{50}: 2.3 \times 10^{-7}$ vs $\left.6.8 \times 10^{-9} \mathrm{M}\right)$. Interestingly, even a linear formylated analogue, [Ala ${ }^{11,15}$, $\left.\operatorname{Trp}(\text { For })^{21}\right]$ ET-1(9-21), showed a selective ET $_{\mathrm{A}}$ activity $\left(\mathrm{EC}_{50}: 3.0 \times 10^{-6} \mathrm{M}\right)$. These peptides are the first com-

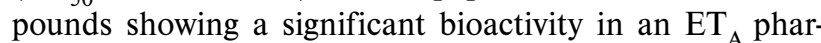
macological preparation while being inactive in an $\mathrm{ET}_{\mathrm{B}}$ paradigm (20).

As regard $\mathrm{ET}_{\mathrm{B}}$ receptor, sarafotoxin $\mathrm{S} 6 \mathrm{c}$ and the truncated, linear synthetic analogues BQ3020 ([Ala $\left.{ }^{11,15}\right]$ acetylET-1-(6-21)) (15) and IRL1620 (Suc-[Glu $\left.{ }^{9}, \mathrm{Ala}^{11,15}\right] \mathrm{ET}-$ 1-(8-21)]) (33) are the most widely used selective agonists for characterizing $\mathrm{ET}_{\mathrm{B}}$ receptors. Radiolabelled analogues $\left[{ }^{125} \mathrm{I}\right] \mathrm{BQ} 3020$ and $\left[{ }^{125} \mathrm{I}\right]$ IRL1620 are also commercially available. Some other peptide and/or non-peptide selective agonists of $\mathrm{ET}_{\mathrm{B}}$ receptor are given in Tab. 2.

\section{Endothelin receptors antagonists}

Antagonists are classified as $\mathrm{ET}_{\mathrm{A}^{-}}$-selective, $\mathrm{ET}_{\mathrm{B}}$-selective, or non-selective mixed antagonists that display similar affinities for both receptor subtypes. However, only $\mathrm{ET}_{\mathrm{A}}$-selective or $\mathrm{ET}_{\mathrm{A}} / \mathrm{ET}_{\mathrm{B}}$ antagonists are currently being evaluated in clinical trials. Nevertheless, $\mathrm{ET}_{\mathrm{B}}$-selective antagonists are also known.

The most highly selective peptide antagonists (4-5 orders of selectivity) for the $\mathrm{ET}_{\mathrm{A}}$ receptors are the cyclic pentapeptide BQ123 (cyclo-[D-Asp-L-Pro-D-Val-L-Leu-D-Trp-]) (24) and the modified linear peptide FR139317 (N-[(hexahydro-1-azepinyl)carbonyl]L-Leu(1-Me)D-Trp ${ }^{3}$ (2-pyridyl)D-Ala)) (29). A peptide structurally similar to FR139317 has been radiolabelled, [ $\left.{ }^{125} \mathrm{I}\right] \mathrm{PD} 151242$, which displays subnanomolar affinity for the $\mathrm{ET}_{\mathrm{A}}$ subtype (7). BQ123 is also available as a tritiated analogue, and a non-peptide antagonist, $\left[{ }^{125}\right.$ I]PD 164333, displays high affinity and selectivity for this subtype.

Generally more potent non-peptide antagonists for the $\mathrm{ET}_{\mathrm{A}}$ receptors, such as PD156707, SB234551, L754142,
A127722, and TBC11251 are known and some of them are characterized in Tab. 2.

A limited number of peptide (BQ788) and non-peptide (A192621) $\mathrm{ET}_{\mathrm{B}}$ antagonists have also been developed. Some of them are summarized in Tab. 2. They are generally less potent than $\mathrm{ET}_{\mathrm{A}}$ antagonists and display lower selectivity (usually only 1 to 2 orders of magnitude) for the $\mathrm{ET}_{\mathrm{B}}$ receptor. Radioligands highly selective for either $\mathrm{ET}_{\mathrm{A}}$ ( ${ }^{125} \mathrm{I}-\mathrm{PD} 151242,{ }^{125} \mathrm{I}-\mathrm{PD} 164333$, and $\left.{ }^{3} \mathrm{H}-\mathrm{BQ} 123\right)$ or $\mathrm{ET}_{\mathrm{B}}$ receptors $\left({ }^{125} \mathrm{I}-\mathrm{BQ} 3020\right.$ and ${ }^{125}$ I-IRL 1620) have further consolidated classification into only these two types, with no strong molecular or pharmacological evidence to support the existence of further receptors in mammals.

\section{Endothelin receptors antagonists in clinical development}

While peptide antagonists are useful as research tools, their therapeutic use is limited by the fact that they can only be administered i.v. and have a short duration of action. Being peptides, they are degraded in the gastrointestinal tract by proteolytic enzymes.

The limitations of peptide antagonists have been partly overcome by non-peptide antagonists (5). ET receptors antagonists in clinical trial are summarized in Tab. 3. Manipulation of the activity of ET-1, especially using ET receptor antagonist, has allowed the further elucidation of the role of this neurohormonal system and development of novel therapeutic strategies in the treatment of heart failure (28). To date, published clinical studies of these agents have involved relatively small numbers of patients with severe heart failure, followed for a relatively short time period, and have mainly examined surrogate endpoints. Large-scale trials that address to significant clinical outcomes are ongoing and their results forthcoming. A key question that remains is whether selective $\mathrm{ET}_{\mathrm{A}}$ or dual $\mathrm{ET}_{\mathrm{A}} / \mathrm{ET}_{\mathrm{B}}$ receptor blockade will be more effective (1).

The same refers to utilization of ET antagonists in other pathological conditions, such as pulmonary arterial hypertension $(\mathrm{PAH})$, subarrachnoid hemorrhage or hepatorenal syndrome. Bosentan (Tracleer) (Fig. 2) was the first ET antagonist approved by the Food and Drug Administration for the treatment of pulmonary arterial hypertension (8) and recently tezosentan (Veletri) has been designated for the same indication (17) and is under investigation for acute heart failure. The development of bosentan, a novel, well-tolerated, orally active endothelin antagonist, has significantly changed the therapeutic approach to PAH. Recent clinical trials have demonstrated that treatment with bosentan produces favourable effects on cardiopulmonary haemodynamics (22). Also tezosentan, dual $\mathrm{ET}_{\mathrm{A}} / \mathrm{ET}_{\mathrm{B}}$ receptor antagonist that has demonstrated efficacy in improving cardiac index and reducing pulmonary capillary wedge pressure in patients with acute, decompensated heart failure, was introduced into clinical practice recently (31). 
Tab. 3: Classification of ET receptor antagonists in clinical development.

ET receptors antagonists in II and III phase of clinical trials. CHF, congestive heart failure; PH, primary pulmonary hypertension; PC, prostate cancer; PORH, portal hypertension, SAH, subarachnoid hemorrhage; HRS, hepatorenal syndrome.

\begin{tabular}{|c|c|c|c|c|c|}
\hline Commercial name & Generic name & Company code & Selectivity & Clinical trial & Target \\
\hline Tracleer & Bosentan & RO470203 & $\mathrm{ET}_{\mathrm{A}} / \mathrm{ET}_{\mathrm{B}}$ & $\begin{array}{l}\text { REACH-1 } \\
\text { EARLY } \\
\text { ENABLE-1 to }-2 \\
\text { BUILD-1 to }-2 \\
\text { RAPIDS-1 to }-2 \\
\text { BREATHE-1 to }-4\end{array}$ & $\begin{array}{l}\text { CHF } \\
\text { CHF } \\
\text { CHF } \\
\text { PH }\end{array}$ \\
\hline & & $\begin{array}{l}\text { TAK044 } \\
\text { SB209670 } \\
\text { PD156707 (=CI1020) }\end{array}$ & $\begin{array}{l}\mathrm{ET}_{\mathrm{A}} / \mathrm{ET}_{\mathrm{B}} \\
\mathrm{ET}_{\mathrm{A}} / \mathrm{ET}_{\mathrm{B}} \\
\mathrm{ET}_{\mathrm{A}}\end{array}$ & $\mathrm{CHF}$ & PORH \\
\hline & $\begin{array}{l}\text { Darusentan } \\
\text { Enrasentan }\end{array}$ & $\begin{array}{l}\text { LU135252 } \\
\text { SB217242 }\end{array}$ & $\mathrm{ET}_{\mathrm{A}}$ & $\begin{array}{l}\text { EARTH } \\
\text { FNCOR }\end{array}$ & $\mathrm{CHF}$ \\
\hline & $\begin{array}{l}\text { Enrasentan } \\
\text { Sitaxsentan }\end{array}$ & $\begin{array}{l}\text { SB217242 } \\
\text { TBC11251 }\end{array}$ & $\begin{array}{l}\mathrm{ET}_{\mathrm{A}} / \mathrm{ET}_{\mathrm{B}} \\
\mathrm{ET}_{\mathrm{A}}\end{array}$ & $\begin{array}{l}\text { ENCOR } \\
\text { PC }\end{array}$ & \\
\hline & Atrasentan & ABT627 & $\mathrm{ET}_{\mathrm{A}}$ & & \\
\hline \multirow{3}{*}{ Veletri } & Ambrisentan & LU 208075 (=BSF-208075) & $\mathrm{ET}_{\mathrm{A}}$ & ARIES I \& II, & CHF \\
\hline & Tezosentan & RO610612 & $\mathrm{ET}_{\mathrm{A}} / \mathrm{ET}_{\mathrm{B}}$ & $\begin{array}{l}\text { RITZ-1 to }-4 \\
\text { VERITAS-1 to }-2\end{array}$ & $\begin{array}{l}\text { SAH } \\
\text { HRS }\end{array}$ \\
\hline & Clazosentan & & $\mathrm{ET}_{\mathrm{A}}$ & & SAH \\
\hline
\end{tabular}<smiles>COc1ccccc1Oc1c(NS(=O)(=O)c2ccc(C(C)(C)C)cc2)nc(-c2ncccn2)nc1OCCO</smiles>

Fig. 2: Chemical structure of bosentan (Tracleer), the first endothelin receptor antagonist approved by the Food and Drug Administration for the treatment of pulmonary arterial hypertension.

\section{Conclusions}

The ET system plays an important role in the pathophysiology of a variety of cardiovascular diseases including congestive heart failure, essential and pulmonary hypertension, renal failure, and cerebrovascular disease. The biological effects of ET-1 on its target organs are mediated by two receptor types: $\mathrm{ET}_{\mathrm{A}}$ and $\mathrm{ET}_{\mathrm{B}}$. It is widely accepted that the vascular, cardiac, and renal adverse effects of ET-1 are mediated by $\mathrm{ET}_{\mathrm{A}}$, while activation of $\mathrm{ET}_{\mathrm{B}}$ receptors leads to beneficial effects such as: attenuating the vascular and cardiac hypertrophic effects of ET-1 as well as they mediate the vasodilatory action of this peptide (activation of $\mathrm{ET}_{\mathrm{B} 1}{ }^{-}$ receptor subtype). In the last decade, a plenty of peptide and non-peptide ET-1 antagonists have been developed. Several clinical studies have revealed that ET-1 antagonists are clinically beneficial therapeutic agents for the treatment of several cardiovascular diseases, leading to the approval of bosentan ( $\mathrm{ET}_{\mathrm{A}} / \mathrm{ET}_{\mathrm{B}}$ antagonist) for the treatment of pulmonary hypertension.

\section{References}

1. Abassi Z, Ramadan R, Schwartz H, Hoffman A. Therapeutic implications of endothelin antagonists for cardiovascular diseases (Article in Hebrew). Harefuah 2004:143:47-53, 84 .

2. Arai H, Hori S, Aramori I, Ohkubo H, Nakanishi S. Cloning and expression of a cDNA encoding an endothelin receptor. Nature (London) 1990;348:730-2.

3. Bdolah A, Wollberg Z, Fleminger G, Kochva E. SRTX-d, a new native peptide of the endothelin/sarafotoxin family. FEBS Lett 1989;256:1-3.

4. Becker A, Dowdle EB, Hechler U, Kauser K, Donner P, Schleuning WD. Bibrotoxin, a novel member of the endothelin/sarafotoxin peptide family, from the venom of the burrowing asp Atractaspis bibroni. FEBS Lett 1993;315:100-3.

5. Davenport AP, Battistini B. Classification of endothelin receptors and antagonists in clinical development. Clin Sci 2002;103:1S-3S.

6. Davenport AP. Endothelin receptors. In: The IUPHAR Compendium of Receptor Characterisation and Classification, 2nd edn, London: IUPHAR Media, 2000:182-8.

7. Davenport AP, Kuc RE, Hoskins SL, Karet FE, Fitzgerald F. [125I]-PD151242: a selective ligand for endothelin $\mathrm{ET}_{\mathrm{A}}$ receptors in human kidney which localizes to renal vasculature. Br J Pharmacol 1994;113:1303-10.

8. Davenport AP, Maguire JJ. Of mice and men: advances in endothelin research and first antagonist gains FDA approval. Trends Pharmacol Sci 2002;23:155-7.

9. D'Orleans-Juste P, Plante M, Honore JC, Carrier E, Labonte J. Synthesis and degradation of endothelin-1. Can J Physiol Pharmacol 2003;81:503-10.

10. Gavornik P, Bremserová E, Pilarčíková A. Endotelová dysfunkcia - ústredný klinický problém angiológie a praktickej klinickej medicíny v súčasnosti. Med Milit Slovaca 2003;5:30-7.

11. Gray AG, Webb DJ. The endothelin system and its potential as a therapeutic target in cardiovascular disease. Pharm Ther 1996;72:109-48. 
12. Haynes WG. Webb DJ. The endothelin family of peptides: local hormones with diverse roles in health and disease. Clin Sci 1993:84:485-500.

13. Howard PG, Plumpton C, Davenport AP. Anatomical localisation and pharmacological activity of mature endothelins and their precursors in human vascular tissue. J Hypertens 1992;10:1379-86.

14. Inoue A, Yanagisawa M, Kimura S. The human endothelin family: three structurally and pharmacologically distinct isopeptides predicted by three separate genes. Proc Natl Acad Sci USA 1989;86:2863-7.

15. Karet FE, Kuc RE, Davenport AP. Novel ligands BQ123 and BQ3020 characterize endothelin receptor subtypes $\mathrm{ET}_{\mathrm{A}}$ and $\mathrm{ET}_{\mathrm{B}}$ in human kidney. Kidney Int 1993;44:36-42.

16. Kolb E. Endothelins - properties, formation, mechanism of action and significance (Article in German) Z Gesamte Inn Med 1991;46:355-60

17. Krum H, Liew D. New and emerging drug therapies for the management of acute heart failure. Intern Med J 2003;33:515-20.

18. Kurnik D, Haviv Y, Kochva E. A snake bite by the Burrowing Asp, Atractaspis engaddensis. Toxicon 1999;37:223-7.

19. Kusserow H, Unger T. Vasoactive peptides, their receptors and drug development. Basic Clin Pharmacol Toxicol 2004;94:5-12.

20. Langlois C, Letourneau M, Lampron P, St-Hilaire V, Fournier A. Development of agonists of endothelin-1 exhibiting selectivity towards ETA receptors. $\mathrm{Br}$ J Pharmacol 2003;139:616-22.

21. Liu S, Premont RT, Kontos CD, Huang J, Rockey DC. Endothelin-1 activates en dothelial cell nitric-oxide synthase via heterotrimeric G-protein beta-gamma subunit signaling to protein kinase B/Akt. J Biol Chem 2003;278:49929-35.

22. O'Callaghan D, Gaine SP. Bosentan: a novel agent for the treatment of pulmonary arterial hypertension. Int J Clin Pract 2004;5:69-73.

23. Patočka J, Měrka V, Hrdina V, Hrdina R. Endothelins and sarafotoxins: peptides of similar structures and different function. Acta Med (Hradec Králové) 2004 47:157-62.

24. Peishoff CE, Janes RW, Wallace BA. Comparison of the structures of the endothelin A receptor antagonists BQ123 and N-methyl leucine BQ123 with the crystal structure of the C-terminal tail of endothelin-1. FEBS Lett 1995;374:379-83.

25. Pinet F. What is the role of endothelin system? (Article in French). Med Sci (Paris) 2004;20:339-45
26. Potaczek DP, Sanak M Endothelin-biosynthesis, function and role in cardiovascular diseases. (Article in Polish). Pol Arch Med Wewn. 2002;108:703-14.

27. Rubanyi GM, Botelho LH. Endothelins. FASEB J 1991:5:2713-20.

28. Sharma M, Teerlink JR. A rational approach for the treatment of acute heart failure: current strategies and future options. Curr Opin Cardiol 2004;19: 254-63.

29. Sun XY, Hedner T, Feng Q, Edvinsson L. Inhibition of endothelin (ET-1) induced pressor responses by the endothelin $\left(\mathrm{ET}_{\mathrm{A}}\right)$ receptor antagonist FR139317 in the pithed rat. Blood Press 1992;1:108-12.

30. Takasaki C. Sarafotoxin (Article in Japanese) Seikagaku 1993;65:189-93.

31. Tovar JM, Gums JG. Tezosentan in the treatment of acute heart failure. Ann Pharmacother 2003;37:1877-83.

32. Yanagisawa M, Kurihara H, Kimura S. A novel potent vasoconstrictor peptide produced by vascular endothelial cells. Nature 1988;332:411-5.

33. Yukimura T, Yamashita Y, Miura K et al. Renal vasodilating and diuretic actions of a selective endothelin $\mathrm{ET}_{\mathrm{B}}$ receptor agonist, IRL1620. Eur J Pharmacol 1994; 264:399-405.

34. Weiser E, Wollberg Z, Kochva E, Lee SY. Cardiotoxic effects of the venom of the burrowing asp, Atractaspis engaddensis (Atractaspididae, Ophidia). Toxicon 1984; 22:767-74.

Submitted September 2004

Accepted November 2004.

Prof. RNDr. Jiři Patočka, DrSc., University of Defense in Brno,

Faculty of Military Health Sciences in Hradec Králové, Department of Toxicology, 50001 Hradec Králové, Czech Republic. e-mail: patocka@pmfhk.cz 